\title{
PILOT SCALE PRODUCTION OF IRRADIATED NATURAL RUBBER LATEX AND ITS DIPPING PRODUCTS
}

\author{
Marga Utama ${ }^{1}$, Meri Suhartini ${ }^{1}$, Herwinarni ${ }^{1}$, Siswanto $^{2}$, Yoharmus \\ S. $^{3}$, H.Sundaru ${ }^{4}$, H.M.Halik ${ }^{5}$, Prayitno ${ }^{6}$, H.M.Muklis ${ }^{7}$, Sunardi Ruslim ${ }^{8}$. \\ 1. Center for R\&D of Isotopes and Radiation Technology, National Nuclear energy Agency, Jakarta. \\ 2. Indonesian Biotechnology Research Institute for Estate Crops, Bogor. \\ 3. Bogor Research Center for Rubber Technology. \\ 4. Faculty of Medicine, Indonesian University, Jakarta. \\ 5. Government-owned Esatae VIII (PTPN VIII), Bandung. \\ 6. PT. Mitra Rajawalli Banjaran, Bandung. \\ 7. PT. Sugih Instrumendo Abadi, Padalarang. \\ 8. PT. Laxindo Utama, Serang, Banten.
}

\begin{abstract}
PILOT SCALE PRODUCTION OF IRRADIATED NATURAL RUBBER LATEX AND ITS DIPPING PRODUCTS. One hundred and fifty $\mathrm{kg}$ natural rubber latex (NRL) before and after concentration were added with $3 \mathrm{phr}$ (part hundred ratio of rubber) normal butyl acrylate, then the mixture were irradiated at $25 \mathrm{kGy}$ by gamma rays of ${ }^{60} \mathrm{Co}$ in pilot scale. The irradiated natural rubber latex (INRL) were then being to use for producing rubber products such as condom, surgical gloves, and spygmomanometer in factory scale. The quality of INRL and rubber products such as : total solid content (TSC), dry rubber content (DRC), KOH, VFA and MST number, tensile strength, modulus, elongation at break, extractable protein content, and response against Type I allergy etc. were evaluated. The economic aspect for producing INRL by means of Gamma Irradiator (GI) and Electron Beam Machine (EBM) such as payback period (PP), net present value (NPV) and internal rate return (IRR) were calculated. The results showed that the latex properties of INRL such as DRC, TSC, KOH, VFA, and MST number are not only found to the requirement of the ISO 2004 standard but also the latex has low protein, lipid, and carbohydrate content. The physical and mechanical properties (tensile strength, modulus, and elongation at break) of rubber dipping products such as condom, gloves, and sphygmomanometer are not only found to the requirement of ISO 4074, ISO 10282, and ANSI/AAMI SP-1994 standards, but also the allergic response tested clinical latex-sensitive protein allergen by ELISA test on gloves, and by SPT test on condom are found to be negative. It indicates that production of INRL or PVNRL or RVNRL by EBM $250 \mathrm{keV} / 10 \mathrm{~mA}$, was more cheap than by using gamma $\gamma$ irradiator $200 \mathrm{kCi}$, or sulfur vulcanization. The value of PBP (payback period) was 2,1 years, NPV (net present value) was 4,250 US \$, PI (profitability index) 1,06 and IRR (internal rate of returns) was $25,0 \%$.
\end{abstract}

Key words : irradiated natural rubber latex, allergic response, techno-economical aspect.

\section{INTRODUCTION}

Indonesia is the second largest of rubber production country in the world with total production in 2003 was around 1.589 million ton, but the local consumption of rubber around 116.000 ton or $7.3 \%$ from the total of Indonesian production[1]. The production of rubber dipping products increased from year to year such as in 2000 the total production of gloves was 5.2 million pcs., in 2001/2001 6 pcs., and in October 2003 increases 15\% about 6.2 million pcs[2]. 
Natural rubber latex (NRL) has a specific competitive against latex synthetic since it lower in price, renewable, good in wet strength and elastic as well as good in barrier properties, and it due widely used in medical devices such as for anesthesia (heating circuit, indotracheal tubes) for dumbel (bite, block, dental dum, etc), for general medical (medical gloves, hot water bottle, blood pressure cuft etc.), for surgical /urological (arterial and venous catheter, surgical gloves, etc.), and in various field such as : sealing compound adhesive, sphygmomanometer, condom, and like[3-6].

The pre-dominant use of NRL is in the production of dipped goods, where its superior film forming ability, excellent gel strength and high tensile strength and elongation required for the finish product are essential. How ever the incidence of latex allergy associated with water-extractable protein in gloves, of Type I hyper-sensitivity has posed a serious challenge to latex dipping products manufactures[7-10].

The Indonesian Nuclear energy Agency has established a commercial pilot plant for producing irradiated natural rubber latex (INRL)) by gamma irradiation as a energy for vulcanization since 1983[11-14]. This INRL has used for production of foam rubber, condom, examination glove, and rubber thread, in factory scale [15-19]. The physical and mechanical properties of film from rubber products such as condom, examination gloves, were satisfy to standards requirement, but the sticky problem among rubber products during production was occur. The maximum volume for producing rubber foam was 9 times, and for improvement the modulus of rubber treat the compound should be bland with natural rubber grafted methyl methacrylate copolymer (NR-g-MMA).

This paper describes a trial production of INRL and its rubber dipped product which has been carried out in factory scale through the National Cooperation between R\&D Indonesia Governments Institutions with the Indonesian Rubber Industries. The purpose of this study is to prove that the process for production of INRL can be produced in pilot scale, with good quality of its rubber products, and the economical aspect is competitive compared with sulfur vulcanization method.

\section{MATERIAL AND METHOD}

Material. The material for implementation this research divided into 5 kinds : 1)The raw material for producing INRL such as field natural rubber latex with concentration of ammonia was around 1-2\%, and high ammonia (HA) centrifuged latex were prepared Jalupang centrifuged NRL factory PTP VIII Subang, Bandung, West Jawa, Indonesia. 2) The chemicals for producing INRL such as: nonionic soap, $\mathrm{KOH}, \mathrm{nBA}$ (normal butyl acrylate) etc.were prepared by National Nuclear energy Agency (BATAN) Jakarta, 3) The chemical for producing condom such as : antitack G, antitack $\mathrm{K}$, silicon oil etc. were prepared by condom factory PT MRB Bandung 4) 
The chemical for producing sphygmomanometer such as calcium nitrate, ammonia, etc. were prepared by sphygmomanometer factory PT.SIA Padalarang, 5) The chemical for producing gloves such as calcium nitrate, non ionic soap, etc.prepared by golves factory PT. Laxindo Utama Serang Banten and the chemical for response analysis of allergic such as acrylamide, glycerol, etc. were prepared by Indonesian Biotechnology Research Institute for Estate Crops, Bogor. and Faculty of Medicine, Indonesian University, Jakarta.

Apparatus. There are 5 kinds apparatus for implementation the research :1) Latex irradiator prepared by Center for R\&D of Isotopes and Radiation Technology, National Nuclear energy Agency, Jakarta, 2) The Condo factory prepared by at PT.Mitra Rajawali Banjaran Bandung, 3) The Sphygmomanometer factory prepared by PT. Sugih Instrumendo Abadi Padalarang Bandung, 4) The Gloves factory prepared by PT. Laxindo Utama Serang Banten, and 5) Apparatus for testing of allergic response, quality of latex and its rubber products, prepared by Indonesian Biotechnology Research Institute for Estate Crops, Research Center for Rubber Technology Bogor, and Faculty of Medicine, Indonesian University, Jakarta.

Method. The research strategy implementation for this project is shown on Figure 1. This project has been carried out in 2001 to 2004 through the National Cooperation between R\&D Indonesia Governments Institutions and the Indonesian Rubber Industries (RUK VII 2001-2002 and IPTEKDABATAN 2003-2004). From this figure it can be seen that there are two
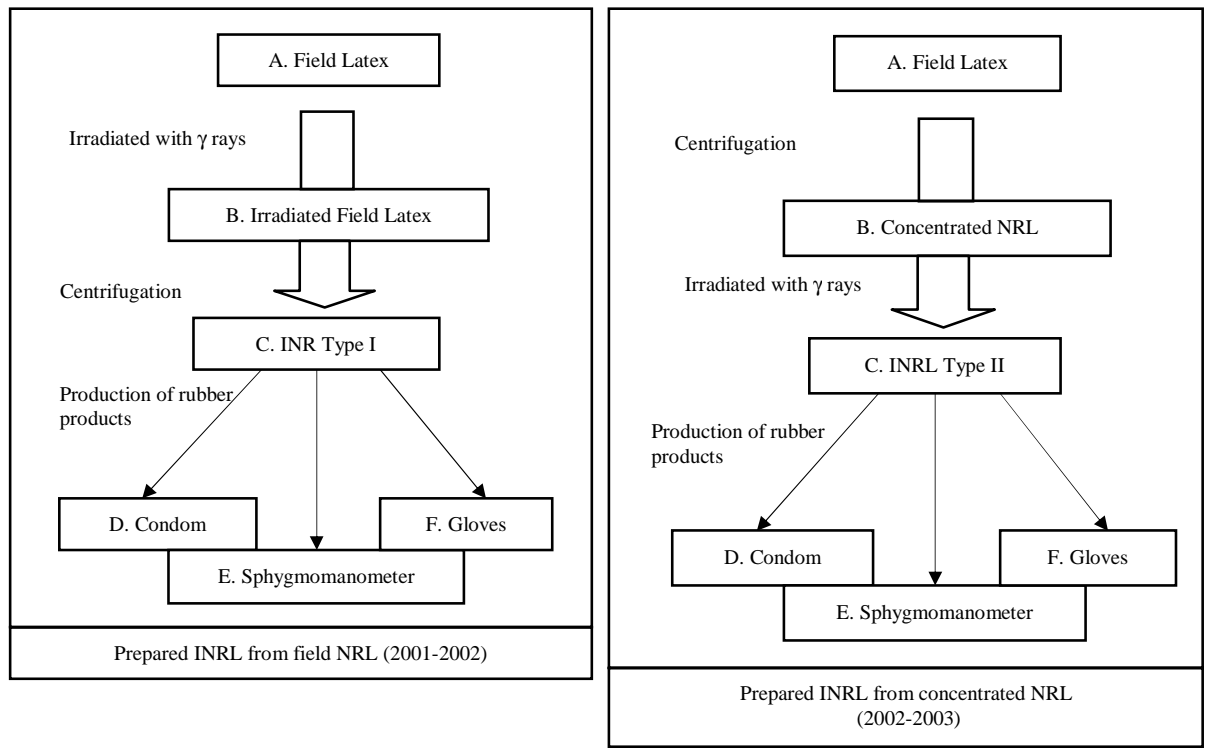

Figure 1. Strategy of trial production of INRL from field and concentrated NRL, and its rubber product in pilot scale. 
methods for producing INRL in pilot scale namely : A) Preparation of INL from field NR and B) Preparation of INRL from concentrated NRL with the procedure from both methods are as follow:

Production of INRL from filed NRL. The field NRL were irradiated by gamma rays in pilot scale at BATAN Jakarta, then after irradiation irradiated field latex were centrifuged at Jalupang NRL factory Subang Bandung. The INRL produced by this method is called INRL Type I.

Production of INRL from concentrated NRL. The field NRL were concentrated at Jalupang NRL factory Subang Bandung then the concentrated NRL were irradiated at BATAN Jakarta. The INRL produced by this method is called INRL Type II.

Production of condom from INRL Type I or Type II. The INRL Type I or Type II were sent to condom factory at Banjaran Bandung. The procedure for producing condom is quite the same with the producing of condom from sulfur vulcanization method.

Production of surgical gloves from INRL Type I or Type II. The INRL Type I or Type II were sent to glove factory at Serang. The procedure for producing of surgical gloves is quite the same with the producing surgical gloves from sulfur vulcanization method.

Production of spygmomanometer from INRL Type I or Type II. The INRL Type I or Type II were sent to spygommomanometer factory at Padalarang Bandung. The procedure for producing spygmomanometer is quite the same with the producing of spygmomanometer from sulfur vulcanization method.

Evaluation the quality of INRL and its rubber products. The procedure for evaluation the quality of INRL and its rubber product were carried out according to the references number 20,21,22,23,24, and 25. [20-25].

Method for techno-economic of INRL. The first step was to know the price of machine for producing INRL such as : latex irradiator, electron beam machine, etc. as an fix capital. Then to calculate the payback period (PP), net present value (NPV), profitability index (PI) and internal rate of return (IRR) of INRL with capacity production 1000 ton INRL/year according to reference number 26 [26].

\section{RESULTS AND DISCUSSION}

\section{Trial production of INRL}

Effect of ionizing radiation (gamma rays or electron beam) on polymeric materials has been studied since for over than 40 years a go by a number of investigators. It was reported that the effect on polymeric materials are degradation and cross-linking. Both degradation and crosslinking may occur simultaneously. In cross-linking occur at a high yield appear chain scission in the same polymer, the polymer is classified as a 
cross-linking polymer. On the other hand of the chain scission yield is higher than cross-linking in the same polymer, the polymer is classified as a degradable polymer [27-28].

The effect of gamma irradiation or electron beam on field NRL not only occur cross-link among cis 1,4 poly-isoprene, but also degradation on non rubber constituent. So it can be called that NRL after irradiation is irradiated natural rubber latex.

Field NRL is a suspension of cis 1,4 poly-isoprene (30-35\%) of natural rubber particle which range in diameter from $0.5 \mu$ to $2.0 \mu$ in non rubber constituent. The non rubber constituent in field NRL are protein (1-2\%), lipids (1-2\%), phospholipid (0,5-1\%), carbohydrate (1.5-2.0\%), and water $65-70 \%)$ [29-31].

There are two types INRL can be produced by irradiation technique namely INRL Type I and INRL Type II.(Figure 2). The hypothesis for producing INRL type I is to prove that the total solid content (TSC) of Type I is quite the same with the standard specification of concentrated NRL which has standardized by ISO 24004, where the standard TSC of ISO is $61.5 \%$. The detail procedure for producing INRL Type I and II are as follow:

Trial production of INRL Type I. The diagram for producing of INRL Type $I$ is shown Figure 2A: The fresh field latex with total solid content (TSC) $30 \%$ from the truck (A), was transferred into bulb vessel (B), and diluted up to $28 \%$ in sediment vessel tank (C) with $1 \%$ ammonia (D1), and stabilized by $0,2-0,5 \mathrm{phr}$ (part hundred ratio of rubber) of $20 \%$ solution of $\mathrm{KOH}(\mathrm{D} 2)$, then added with $3 \mathrm{phr}$ of $\mathrm{nBA}(\mathrm{G})$ as sensitized. The mixture of fresh field latex from vessel (C) is pumped into reaction vessel (E) and irradiated at $25 \mathrm{kGy}$ by gamma ray from cobalt-60, then transferred into sediment tank vessel (F). The INRL Type I from storage tank (I) can be obtained after irradiated field NRL from sediment tank $(\mathrm{F})$ was centrifuged by centrifuge machine $(\mathrm{H})$, and added with sodium laurate $0.02 \mathrm{phr}(\mathrm{J})$
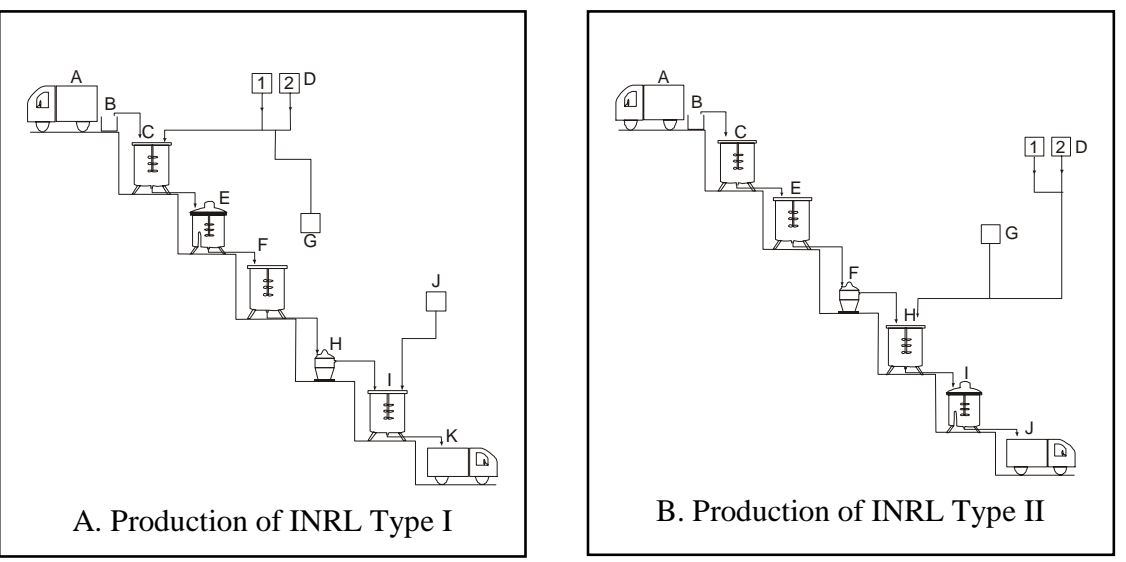

Figure 2. Production of INRL Type I and Type II, by gamma irradiation technique. 
Trial production of INRL Type II. The trial production of INRL Type II is shown on Figure 2B. The INRL Type II can be obtained is as follows : The centrifuged NRL with total solid content $60 \%$ from reaction vessel $(\mathrm{H})$ was diluted up to $56-57 \%$ with $1 \%$ solution of ammonia (D1), then stabilized with $0,2-0,5 \mathrm{phr}$ of $20 \%$ solution of $\mathrm{KOH}$ (D2), left over night, and then added with $3 \mathrm{phr}$ of $50 \%$ emulsion of $\mathrm{nBA}$ from reaction vessel $(G)$, and irradiated by gamma ray from cobalt- 60 .

Table 1. Quality of INRL

\begin{tabular}{|l|c|c|c|}
\hline \multirow{2}{*}{ Characteristic } & \multicolumn{2}{|c|}{ INRL } & \multirow{2}{*}{$\begin{array}{c}\text { ISO 2004 } \\
\text { Standard }\end{array}$} \\
\cline { 2 - 3 } & Type 1 & Type 2 & $61.5^{*}$ \\
\hline 1. Total solid content (TSC), \%. & 61.5 & 58.5 & $60.0^{*}$ \\
\hline 2. Dray rubber content (DRC), \%. & 60.0 & 57.0 & 2.0 \\
\hline 3. Non-rubber content (TSC-DRC) & 1.5 & 1.5 & 0.6 \\
\hline 4. Alkalinity (as $\mathrm{NH}_{3}$ ), \% on latex. & 0.77 & 0.70 & $650^{*}$ \\
\hline 5. Mechanical stability time (MST), second. & 1500 & 1500 & $0.05^{* *}$ \\
\hline 6. Coagulum content, \%. & 0.04 & 0.04 & $8^{* *}$ \\
\hline 7. Copper content, mg/kg. & 2 & 3 & $8^{* *}$ \\
\hline 8. Magnesium content, mg/kg. & 2 & 2 & $0.10^{* *}$ \\
\hline 9. Sludge content, \%. & 0.10 & 0.10 & $0.20^{* *}$ \\
\hline 10. Volatile fatty acid number (VFA). & 0.023 & 0.024 & $1.0^{* *}$ \\
\hline 11. KOH number. & 0,8 & 0,8 & No pronounced blue/gray \\
\hline 12. Color on visual inspection. & \multicolumn{2}{|c|}{ No pronounced of pure active } \\
\hline 13. Odor after netralization with boric acid & \multicolumn{2}{|c|}{} \\
\hline
\end{tabular}

** Maximum, * Minimum

The quality of INRL Type I and II. The quality of INRL Type I and Type II are shown on Table 1. It indicates that the TSC and DRC of INRL Type I are higher than INRL Type II, because for producing the INRL Type I, the first step is to irradiate the field latex, then the irradiated field latex was concentrated by centrifugation machine. This procedure is quite the with the convention procedure for producing $\mathrm{HA}$ concentrated latex which has standardized by ISO 24004, where the standard TSC of ISO is $61.5 \%$. But for producing INRL Type II the first step is to irradiate the HA concentrated latex with TSC 55\%, then before irradiation latex was added by $0,2 \mathrm{phr}$ of KHO $20 \%$ solution, and $3 \mathrm{phr}$ of emulsion n-BA 50\%, so that TSC of INRL is around $57 \%$. The other parameter such as alkalinity, mechanical stability time, coagulant content are quite the same. So INRL Type I is quite the same with the quality of ISO standard.

Tabel 2. Formulation, curing, and properties of INRL film compared with sulfur vulcanization film.

\begin{tabular}{|l|c|c|}
\hline Formulation/curing/properties. & Radiation vulcanization & $\begin{array}{c}\text { Sulfur } \\
\text { vulcanization }\end{array}$ \\
\hline \multicolumn{3}{|c|}{ Formulation } \\
\hline 60\% HA Latex & 100 & 100 \\
\hline 10\% KOH & 0.2 & 0.3 \\
\hline 20\% K.Laurate & 0.2 & 0.3 \\
\hline 25\% Non ionic soap & - & 0.12 \\
\hline $50 \%$ Sulfur & - & 0.7 \\
\hline
\end{tabular}




\begin{tabular}{|c|c|c|c|}
\hline $50 \% \mathrm{ZDEC}$ & \multicolumn{2}{|r|}{-} & 0.4 \\
\hline $50 \%$ ZMBT & \multicolumn{2}{|r|}{-} & 0.3 \\
\hline $50 \% \mathrm{ZnO}$ & \multicolumn{2}{|r|}{-} & 0.5 \\
\hline $50 \%$ Antioxidant & \multicolumn{2}{|r|}{1.0} & 1.0 \\
\hline $50 \% \mathrm{nBA}$ & \multicolumn{2}{|r|}{3.0} & \\
\hline \multicolumn{4}{|l|}{ Curing. } \\
\hline Dose of radiation, kGy. & \multicolumn{2}{|c|}{$25 \mathrm{kGy}$} & 3 \\
\hline Time of maturation, dys. & \multicolumn{2}{|c|}{-} & 3 \\
\hline Temperature of curing, ${ }^{\circ} \mathrm{C}$. & \multicolumn{2}{|r|}{30} & 120 \\
\hline Time of curing, minutes. & \multicolumn{2}{|c|}{10 for EBM, 10 hours for gamma ray } & 15 \\
\hline Properties of vulcanizate film. & INRL Type I & INRL Type II & \\
\hline Modulus $600 \%$, Mpa. & $1.8-2.0$ & $1.8-2.0$ & $3.0-4.0$ \\
\hline Tensile strength, Mpa. & $25-26$ & $25-26$ & $25-30$ \\
\hline Elongation at break, $\%$. & 900 & 900 & 700 \\
\hline $\begin{array}{l}\text { Non rubber content } * \text {. } \\
\text { - Total protein content, } \% \text {. } \\
\text { - Extractable protein content, mg/kg. } \\
\text { - Lipids content, } \% \text {. } \\
\text { - Carbohydrate content, } \% \text {. }\end{array}$ & $\begin{array}{c}0.080 \\
<100 \\
3.67 \\
0.027\end{array}$ & $\begin{array}{l}0.085 \\
<100 \\
3.36 \\
0.030\end{array}$ & $\begin{array}{c}0.29 \\
1000-2000 \\
6.36 \\
0.041\end{array}$ \\
\hline
\end{tabular}

*leaching in amonia $1 \%$ for 15 minutes.

If the INRL is compared with sulfur compound (Table 2), it indicates that key feature of INRL are absence of accelerators, zinc oxide and aminebased accelerator, which can produce nitrosamine, with generic form may be represented by the structure :

$$
{ }^{\mathrm{R}_{1}}>\mathrm{N}-\mathrm{N}=\mathrm{O}
$$

where $R_{1}$ and $R_{2}$ are methylene function group, $N=$ nitrogene, $O=$ oxigen.

This nitrosamines has been shown to be a potent carcinogen in animal tests producing liver, kidney and lung cancer[32].

Absence of the conventional sulfur compound latex accelerators (dithio carbamates and thiazoles) sulfur from INRL ensure that products made from INRL will not caused any dermatitis / allergic reaction associated with these chemicals. Dermatitis (irritation of the skin) from the accelerators, zinc oxide and amine-based accelerator, may be responsible for much of the tissue irritation experienced by patients who have to have latex urinary catheters implanted for long periods.

The absence of zinc and zinc-bearing accelerators eliminates the problem associated with minimizing zinc contents in order to meet regulatory limits for zinc in babies bottle teats, and soothers. The absence of zinc also removes the possibility of trace contamination by lead and cadmium often found in teats and soother, and the absence of amine-based accelerators further means that the possibility of forming nitrosamines during the production of process is eliminated.

The low modulus of INRL film is some advantage for articles such as gloves and toy balloons, where high modulus is not desirable. However, the cross-link density will need to be sufficient to prevent distortion of the 
product on removal from the former. So the modulus value cannot be too low.

Product from INRL should have high transparency, due to the absence of curing ingredients, and this is desirable for products such as teats and soothers and some catheters. Additionally, their should be very pole since they do not need of heated to high temperature for further vulcanization . Also product form INRL should be totally free of the "bloom" problem that are often encountered in conventionally vulcanized, because these blooms are normally the results of excessive level of accelerator or sulfur in the formulation. Compared with sulfur vulcanization it indicates that INRL have low protein, lipids and carbohydrate content to ensure that the finished articles have the minimal amount of residual protein containing the allergens and safe for use.

From these advantages characteristic of INRL, it can be recommended that the potential application of INRL are good for production of medical/surgical products, condom, teats, balloons, and gloves for food contact.

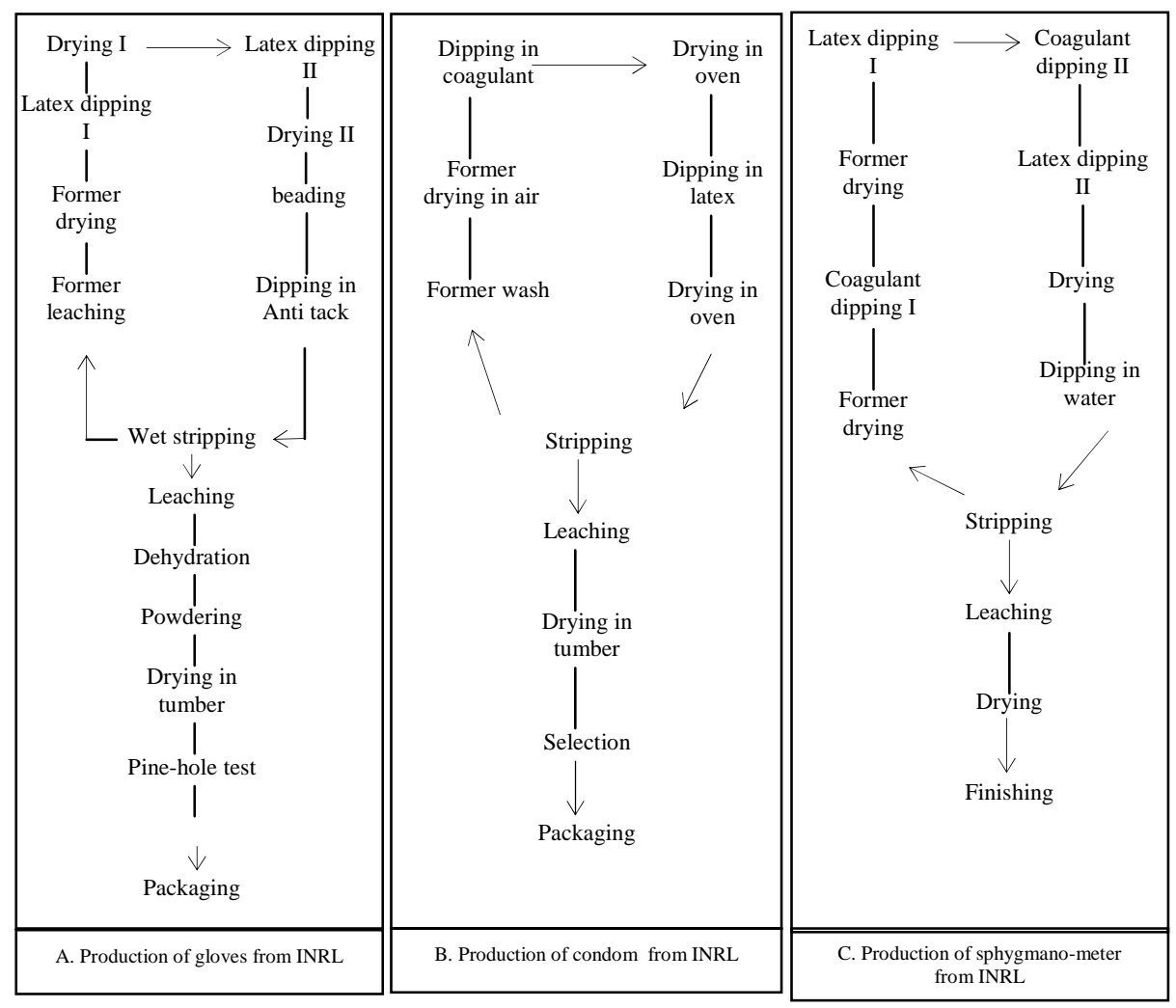

Figure 3. Trial production of gloves, condom, and sphygmomanometer from INRL on factory scale. 


\section{Trial production of dipped products from INRL}

The diagram for production these dipped products are shown on Figure 3, with INRL compound formulation presented in Table 3.

Table 3. Formulation of INRL compound for producing condom, surgical gloves, and rubber for sphygmomanometer.

\begin{tabular}{|l|c|c|c|}
\hline \multirow{2}{*}{ Chemical } & \multicolumn{3}{|c|}{ Part hundred ratio of rubber (phr) } \\
\cline { 2 - 4 } & Condom & Surgical gloves & Sphygmomanometer \\
\hline 60\% INRL Type I & 100 & - & 100 \\
55\% INRL Type II & - & 100 & - \\
20\% Sodium laurate & 0.2 & - & 0.2 \\
50\% antioxidant & 1.0 & 1.0 & 1.0 \\
\hline
\end{tabular}

Trial production of condom in factory scale. Straight dipping for production of condom is the simplest type of dipping process. The thickness of the rubber deposit obtained by this method is dependent only on the total solid content of the latex and its viscosity. Figure 3A shows the diagram of condom production in factory scale. The clean former of condoms immersed into the first INRL compound. The deposit is dried, then immersed again into the second INRL latex compound., dried again, then striped from the former with wet stripping method. The wet condoms are leached, dehydrated, dried in tumbler, dried in air condition, pine hole test selection, lubrication and then packaged. Table 4 shows the relation of condom thickness with total solid content and viscosity of INRL compound . It indicates that for obtaining thickness of condom 50-60 micron, the total solid content should be around $51 \%$.

Table 4. Thickness of condom from INRL with on difference total solid content. (The speed production of condom was 50 gross/hours).

\begin{tabular}{|c|c|c|c|}
\hline Total solid content, $\%$ & Viscosity, cP. & Thickness, $\mu$. & Pine hole, $\%$. \\
\hline 50 & 24 & $40-44$ & 0,99 \\
51 & 26 & $50-60$ & 0,05 \\
52 & 37 & $65-75$ & 0 \\
\hline
\end{tabular}

Condom from INRL produced in factory scale with extractable protein content $116 \mu \mathrm{g} / \mathrm{g}$ showed to give negative response (Table 5). The negative response to Skin-Prick Test of condom prepared from INRL due to the degradation of non rubber content such as extractable protein by gamma radiation[33-34]. 
Table 5. Summary of skin-prick test (SPT).from 11 patients the allergic response by latex hypersensitive individual.

\begin{tabular}{|c|c|c|c|c|c|c|c|c|c|c|c|c|c|}
\hline \multirow[t]{2}{*}{ Samples } & \multirow[t]{2}{*}{$\begin{array}{c}\text { EPC, } \\
\mu / g\end{array}$} & \multicolumn{11}{|c|}{$\begin{array}{l}\text { Individuals hypersensitive SPT, number of } \\
\text { patient. }\end{array}$} & \multirow[t]{2}{*}{$\begin{array}{l}\text { Average, } \\
\text { Au. }\end{array}$} \\
\hline & & 1 & 2 & 3 & 4 & 5 & 6 & 7 & 8 & 9 & 10 & 11 & \\
\hline Control & no data & 0 & 0 & 0 & 0 & 0 & 0 & 0 & 0 & 0 & 0 & 1 & 0.1 \\
\hline $\begin{array}{l}\text { Standard hypersensitivity } \\
\text { latex }\end{array}$ & no data & 2 & 2 & 2 & 2 & 2 & 2 & 2 & 2 & 3 & 2 & 2 & 2.1 \\
\hline $\begin{array}{l}\text { Condom fromsulfur } \\
\text { vulcanization }\end{array}$ & 115 & 2 & 0 & 1 & 0 & 0 & 0 & 0 & 0 & 0 & 0 & 1 & 0.4 \\
\hline $\begin{array}{l}\text { Condom from irradiated } \\
\text { natural rubber latex }\end{array}$ & 116 & 0 & 0 & 0 & 0 & 0 & 0 & 0 & 0 & 0 & 0 & 0 & 0 \\
\hline
\end{tabular}

$\mathrm{EPC}=$ Extractable protein content, Maximum the allergic level response $=4 \mathrm{Au} / \mathrm{g} . \mathrm{Au}=$ allergy unit.

Trial production of surgical gloves in factory scale. Figure $3 \mathrm{~B}$ shows that after leaching and heating, the former is first coated with a layer of coagulant by dipping into a solution of $\mathrm{CaNO}_{3}$ as coagulant agent. The coated former then dipped into irradiated natural rubber latex compound. On coming into contact with the coagulant, the latex is gelled and as diffuses away from the former the gelled layer becomes thicker. The thickness of rubber film produce therefore depends on the dwell time in the latex, concentration and viscosity of coagulant use as well as on the rubber content and viscosity of the latex.

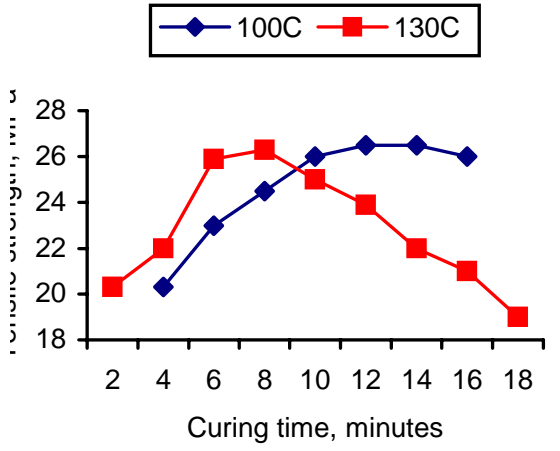

A. Effect of curing time on tensile strength of surgical gloves with temperature on line $100 \& 130^{\circ} \mathrm{C}$

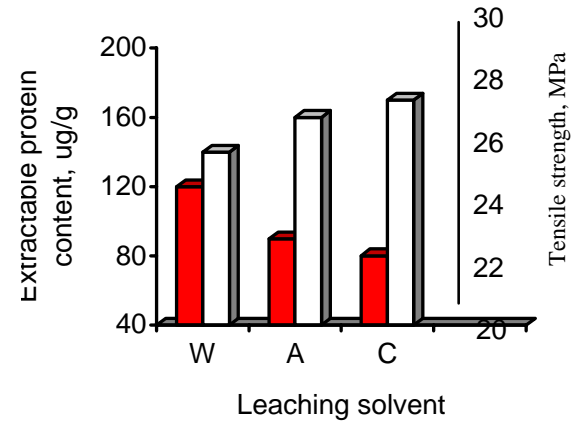

B. Effect of leaching in water (W), $1 \%$ Ammonia (A), $0,01 \%$ cationic soap $(\mathrm{C})$ on the extractable protein content [ ], and tensile strength [ ]

Figure 4. Effect of temperature and heating time on tensile strength (A) and effect of leaching methods on extractable and total protein content (B).

Two factors has been carried out namely: effect of curing time during processing line and effect of leaching time of surgical gloves after powdering and stripping. The results indicates that the optimum drying time in oven with temperature of $100^{\circ} \mathrm{C}$ during processing line is 10 minutes (Figure $4 \mathrm{~A}$ ), 
and the cationic soap is better solvent for leaching minimized because it can the extractable protein content (Figure 4B).

Figure $4 \mathrm{~A}$ shows that by increasing the curing time from 3 to 10 minutes, the tensile strength of gloves increases, then after 10 to 15 minutes the tensile strength of gloves is quite the same. So it can be concluded that the optimum time of curing is 10 minutes. Figure 4B shows that the extractable protein content of gloves after leaching with cationic soap (C) is lesser than the other treatments. It means that the polarity of cationic soap is better than water (W) and ammonia (A) as the leaching solvent. So that the solubility of extractable protein in cationic soap is better than water and ammonia, hence the residue of extractable protein in gloves after leaching with cationic soap is lesser.

$\mathrm{a}=$ not leaching, $\mathrm{b}=$ leaching in water for 6 hours, $\mathrm{c}=$ leaching in water 24 hours, $\mathrm{d}=$ leaching in $1 \%$ amonia/KOH 24

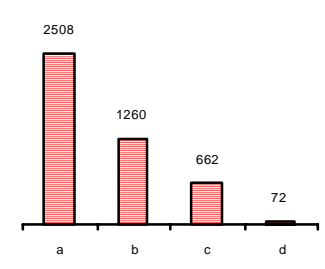

Extractable protein content,u/g

Effect of leaching method on the extractable and total protein content.

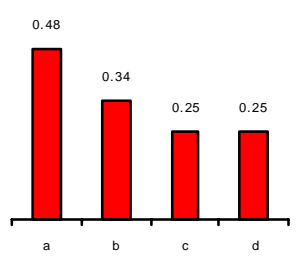

Q T otal protein content, \%

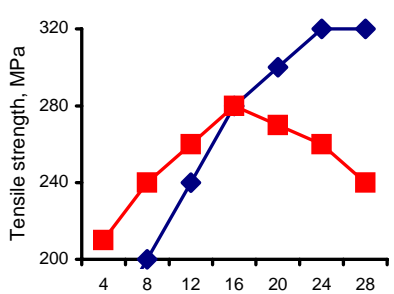

$\longrightarrow$ Sulfur vulcanization $\longrightarrow$-INRL

B. Effect of curing time on the tensile strength of film from INRL and Sulfur vulcanization

Figure 5. The effect of leaching methods on the extractable and total protein content (A), and the effect curing time on the tensile strength of bulb sphygmomanometer (B).

Trial production of rubber for sphygmomanometer in factory scale. There are three kinds of rubber sphygmomanometer has been prepared, namely: bulb, bladder, and tube. The procedure for production of the rubber for sphygmomanometer is coagulant dipping method with two time of dipping in coagulant, and in latex (Figure 3C). The thickness of rubber deposit depends on the dipping time and concentration of coagulant of the second coagulant. The factors such as heating time and leaching of the products has been carried out. The results showed that the leaching agent for production of rubber products was $1 \%$ of ammonia solution (Figure 5A) was the better compared with the other leaching agent such as $\mathrm{KOH}$ and water. The heating time of rubber products from INRL is more shorter than sulfur vulcanization (Figure 5B). 
Figure 5 A shows the residue of extractable content and total protein content of bulb sphygmomanometer not leaching (a) and after leaching in water for 6 hour (b), for 24 hour (c) and leaching in 1\% ammonia or $\mathrm{KOH}$ for 24 hour. It indicates that by increasing of leaching time from 6 to 24 hour in water, the extractable content and total protein content decreases. It means that during prolongation of leaching time, the solubility of protein is running well. Then if the bulb is leached by the $1 \%$ ammonia or $\mathrm{KOH}$ for 24 hour, the extractable protein content decreases from 662 to $72 \mu \mathrm{g} / \mathrm{g}$, it means that the polarity of extractable protein content in ammonia or $\mathrm{KOH}$ is better then water.

Figure $5 \mathrm{~B}$ shows the effect of curing time of INRL and sulfur vulcanization against tensile strength. There are two points which can be seen from this figure: 1) By increasing the tensile strength increases which means the vulcanization occur, but after the over vulcanization the tensile strength decrease. The time which can produce the maximum tensile strength is called optimum cure time such as the optimum cure time of INRL is 15 minutes, but for the sulfur vulcanization is around 24 minutes. 2) The optimum cure vulcanization of INRL is 15 minutes, while the optimum vulcanization of sulfur vulcanization is 24 minutes mean that the in INRL is a pre-vulcanized latex, but in sulfur vulcanization there is not pre-vulcanization. So the time for vulcanization of sulfur vulcanization need more longer time than INRL.

The quality of rubber product from INRL. The quality of condom, surgical gloves, and sphygmomanometer produced in factory scale are shown Table 6. They indicate that the physical of condom, surgical gloves, and sphygmomanometer are not only found to the requirement of ISO 4074-9, ISO 4074-9, and ANSI/AAMI SP-1994 standards, but also the allergic response tested clinical latex-sensitive protein allergen by

Table 6. The quality of condom, surgical gloves, and rubber for sphygmomanometer from INRL produced in factory scale.

\begin{tabular}{|c|c|c|c|c|c|c|c|c|}
\hline \multirow[t]{3}{*}{ Properties } & \multirow[t]{3}{*}{$\begin{array}{l}\text { Treat } \\
\text { ment }\end{array}$} & \multicolumn{2}{|c|}{ Condom } & \multicolumn{3}{|c|}{ Surgical gloves } & \multicolumn{2}{|c|}{$\begin{array}{c}\text { Sphygmomano- } \\
\text { meter bulb }\end{array}$} \\
\hline & & \multirow{2}{*}{ ISO 4074-9 } & \multirow{2}{*}{ INRL } & \multicolumn{2}{|c|}{ ISO 4074-9 } & \multirow{2}{*}{ INRL } & \multirow[t]{2}{*}{ ANSI } & \multirow{2}{*}{ INRL } \\
\hline & & & & Type I & Type II & & & \\
\hline Tensile strength, MPa. & A & 20 & 22 & 23 & 17 & 25 & $\mathrm{Nr}$ & 22 \\
\hline & B & 17 & 18 & 17 & 12 & 20 & $\mathrm{Nr}$ & 20 \\
\hline Elongation at brak, $\%$. & $\mathrm{A}$ & $750^{*}$ & 1000 & $700^{*}$ & $550 *$ & 900 & $\mathrm{Nr}$ & 1000 \\
\hline & $\mathrm{B}$ & $650^{*}$ & 900 & $560^{*}$ & $490^{*}$ & 900 & $\mathrm{Nr}$ & 1000 \\
\hline Modulus 500\%, MPa. & $\mathrm{A}$ & - & - & $3 * *$ & - & - & - & - \\
\hline Bursting strength, liter. & A & $20 *$ & 25 & - & - & - & - & - \\
\hline $\begin{array}{l}\text { Response against Type I } \\
\text { allergic by ELISA test. }\end{array}$ & - & - & - & - & - & negative & - & - \\
\hline $\begin{array}{l}\text { Response against Type I } \\
\text { allergic by SPT test. }\end{array}$ & - & - & negative & - & - & - & - & - \\
\hline
\end{tabular}


ELISA test on gloves and sphygmomanometer produced in factory scale are shown Table 6. They indicate that the physical of condom, surgical gloves, and sphygmomanometer are not only found to the requirement of ISO 40749, ISO 4074-9, and ANSI/AAMI SP-1994 standards, but also the allergic response tested clinical latex-sensitive protein allergen by ELISA test on gloves, and by SPT test on condom are found to be negative. Its means that condom, gloves, and rubber for sphygmomanometer are safe for user.

Table 7. List of INRL pilot plants using gamma rays and electron beam

\begin{tabular}{|l|c|c|c|c|c|}
\hline \multicolumn{1}{|c|}{ Institute } & $\begin{array}{c}\text { BATAN } \\
\text { Jakarta, } \\
\text { Indonesia }\end{array}$ & $\begin{array}{c}\text { Rubber board } \\
\text { Kottayam, } \\
\text { India }\end{array}$ & $\begin{array}{c}\text { MINT Bangi, } \\
\text { Malaysia }\end{array}$ & $\begin{array}{c}\text { Chulalongkorn } \\
\text { University, Bang } \\
\text { kok, Thailand. }\end{array}$ & $\begin{array}{c}\text { TRCRE-JAERI } \\
\text { Takasaki, } \\
\text { Japan. }\end{array}$ \\
\hline Installation year & 1883 & 1992 & 1996 & 1997 & 2001 \\
\hline Size & Commercial & Commercial & Commercial & Laboratory scale & Commercial \\
\hline Process & Batch & Batch & Continuous & Batch & Continuous \\
\hline Designed by & Japan & India & Germany & Hungary & Japan \\
\hline Reactor type & Vessel & Vessel & Tube & Vessel & Vessel \\
\hline $\begin{array}{l}\text { Source } \\
\text { arrangement }\end{array}$ & Inside reactor & Inside reactor & $\begin{array}{c}\text { Outside } \\
\text { reactor }\end{array}$ & Outside reactor & Outside reactor \\
\hline Number of reactor & 1 & 1 & 1 & 4 & 1 \\
\hline $\begin{array}{l}\text { Source storage } \\
\text { type }\end{array}$ & Wet & Wet & Dry & Dry & Dry \\
\hline $\begin{array}{l}\text { Cobalt-60/EB } \\
\text { *Maximum } \\
\text { capacity } \\
* \text { Initial loading }\end{array}$ & $1 \mathrm{MCi}$ & $0,1 \mathrm{MCi}$ & $2 \mathrm{MCi}$ & $10 \mathrm{kCi}$ & $10 \mathrm{~mA}$, \\
\hline INRL capacity & 1,7 ton/batch & 1 ton/batch & $0,2-1,0$ ton/h & 120 liter/batch & 90 liter/h \\
\hline
\end{tabular}

\section{Economical aspect}

Several attempts have been done to evaluate cost production of INRL, which is very important factor before transferring this technology to industry. A few pilot plants

Table 8. Fixed investment and production cost for 1,000 ton / y of INRL (dry rubber base) Type $\mathrm{II}^{*}$ produced by Electron Beam Machine $250 \mathrm{keV} / 10 \mathrm{~mA}$ and ${ }^{60} \mathrm{Co}$ Latex irradiator $200 \mathrm{kCi}$

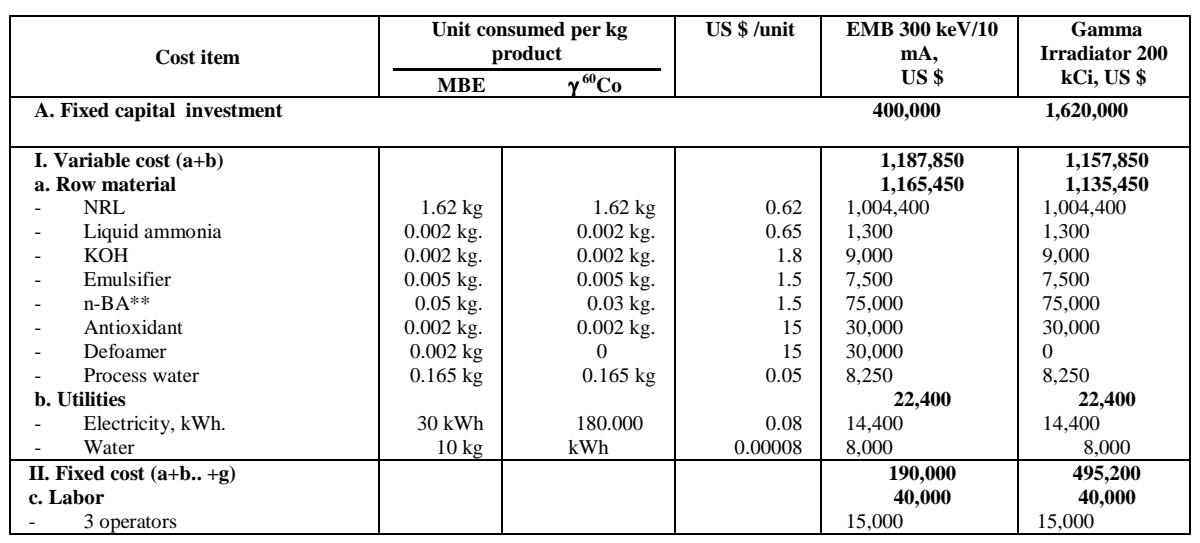




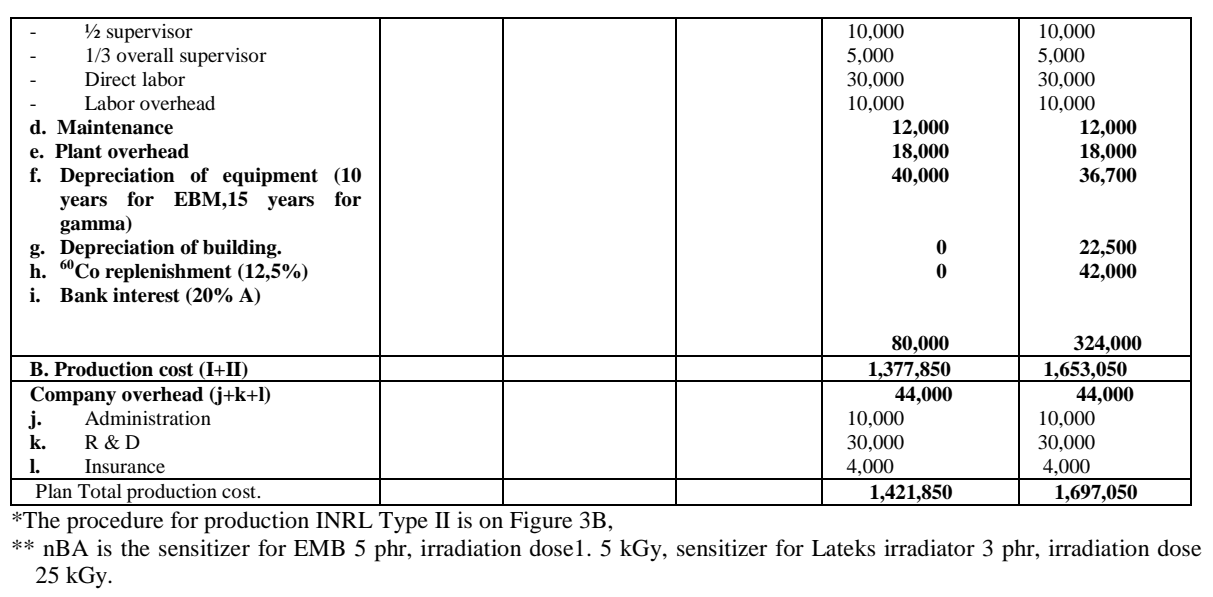

have been constructed to prove the economic feasibility of the INRL process by gamma rays and electron beam irradiation at BATAN Jakarta Indonesia in 1983, Rubber Board Kottayam India in 1992, MINT Bangi Malaysia in 1996, Chulalongkorn University Bangkok Thailand in 1997, and TRCREJAERI Takasaki, Japan in 2000 (Table 7). It had been reported that irradiation cost, which was excluded the sensitizer and antioxidant cost varied large from one country to another, although the method used was almost the same.

Cost analysis of INRL. Production cost of INRL by using normal butyl acrylate $3 \mathrm{phr}$ as sensitize has been done based on the latex Latex Irradiator $\left(\gamma^{60}\right.$-Co $\left.200 \mathrm{kCi}\right)$ pilot plant in Jakarta Indonesia [35], and IMB $250 \mathrm{keV} / 10 \mathrm{~mA}$ in a Southeast Asian country [36] are shown on Table 8. The importance factor for cost analysis of INRL are : Fixed capital investment, variable cost, and fixed cost.

Fixed capital investment. The fixed capital investment for producing INRL by Latex Irradiator $\left({ }^{60} \mathrm{Co} 200 \mathrm{kCi}\right)$ is higher than by using MBE $250 \mathrm{keV} / 10 \mathrm{~mA}$, because the price investment equipments of Latex Irradiator $(1,620,000$ US \$) is higher than MBE such as : the price of water treatment, source handling, mixing tank, reaction vessel, hoist, control panel, source storage, radiation monitor is 550,000 US \$, the budged for building with heavy concrete is 450,000 US $\$$, and the price of cobalt-60 source is 350,000 US $\$$, with contingency about $20 \%$ is 270,000 .US $\$$. While the price of EMB $250 \mathrm{keV} / 10 \mathrm{~mA}$ only 400,000 US \$.

Variable cost. Variable cost for producing INRL by Latex Irradiator $\left(\gamma{ }^{60} \mathrm{Co} 200 \mathrm{kCi}\right)$ is lower than by using MBE $250 \mathrm{keV} / 10 \mathrm{~mA}$, because by using Latex Irradiator does not need defoamer and the consumption of n-BA only $3 \mathrm{phr}$, while using MBE is $5 \mathrm{phr}$.

Fixed cost. The fixed cost for producing INRL INRL by Latex Irradiator $\left(\gamma{ }^{60} \mathrm{Co} 200 \mathrm{kCi}\right)$ is highter than by using MBE $250 \mathrm{keV} / 10 \mathrm{~mA}$, 
because Latex Irradiator is not only high price, but also needs a budged for replenishment of ${ }^{60} \mathrm{Co} 12,5 \%$ per year.

Production cost of INRL. From this calculation there is indication that the production cost of INRL Type II (with 60\% DRC) prepared by EMB $(1,422$ US $\$)$ is lower than by ${ }^{60} \mathrm{Co}(1.700$ US $\$)$, or by sulfur vulcanization $(1,443$ US \$) prepared in India [36]. By using this data, the pay back period (PBP) for producing INRL Type II prepared by EMB $250 \mathrm{keV} / 10 \mathrm{~mA}$ with the sale price like of conventional pre-vulcanized NRL in global market around US \$1.5-2.0/dry kg is shown on Table 9. It indicates that if the sale price of INRL 1.7 US \$, the IRR (internal rate of return) is $25,0 \%$, the PBP is 2,1 years and the net present value (NPV) is 4,250 US \$ and the profitability index $(\mathrm{PI})$ is 1,06

Table 9. The internal rate of return (IRR) and payback period (PBP) production of INRL type II with variation sale price.

\begin{tabular}{|c|c|c|c|c|c|}
\hline $\begin{array}{c}\text { Sales price, } \\
\text { US \$. }\end{array}$ & $\begin{array}{c}\text { Profit } \\
\text { before tax } \\
\text { (A), US \$. }\end{array}$ & $\begin{array}{c}\text { Profit after taxes } \\
\mathbf{3 0 \%} \text { (B), US \$. }\end{array}$ & $\begin{array}{c}\text { Total fixed and } \\
\text { working capital } \\
\text { (C), US \$. }\end{array}$ & $\begin{array}{c}\text { Internal Rate of } \\
\text { Return (B/C), } \\
\text { \%. }\end{array}$ & $\begin{array}{c}\text { Payback } \\
\text { period, year. }\end{array}$ \\
\hline 1.5 & 75,000 & 52,5000 & 755,140 & 7,0 & 7,6 \\
1.6 & 175,000 & 122,500 & 763,473 & 16,0 & 3,3 \\
1.7 & 275,000 & 192,500 & 771,807 & 25,0 & 2,1 \\
1.8 & 375,000 & 262,500 & 780,140 & 33,6 & 1,6 \\
1.9 & 475,000 & 332,500 & 788,473 & 42,2 & 1,3 \\
2.0 & 575,000 & 402,500 & 796,807 & 50,5 & 1,1 \\
2.1 & 675,000 & 472,500 & 805,140 & 58,7 & 0,9 \\
\hline
\end{tabular}

Producing cost rubber products from INRL. The experiences results after trial production of rubber products (condom, or sphygmomanometer) in factory scale showed that the production cost of condom decreased around $30 \%$, and production cost of rubber for sphygmomanometer decreased around $40 \%$.

It is understood that one of the main purpose of this paper is the study of feasibility of manufacturing INRL special emphasis is put on the evaluation of methods to utilized local row materials such as natural rubber latex. The requirements of quality improved and it is therefore assumed that the technical problem are already solved, the economical aspect has been mentioned above, where these technology are going to implementation to industry.

\section{CONCLUSION}

From these study it can be concluded that the production of INRL (irradiated natural rubber latex) and its rubber products in factory scale has been carried out. The quality of latex INRL is not only found to requirements of ISO 2004, but also have low protein, lipid and carbohydrate. The quality of rubber products from INRL such as condom, gloves, and rubber for sphygmomanometer are not only found to requirement of ISO 40074, ISO 
10282, and ANSI/AAMI SP-1994 standards, but also free from nitrosamines and protein allergen. It indicates that for production of INRL or PVNRL or RVNRL by EBM $250 \mathrm{keV} / 10 \mathrm{~mA}$, is more cheap than by using gamma $\gamma$ irradiator $200 \mathrm{kCi}$, or sulfur vulcanization. The value of PBP (payback period) 2,1 years, NPV (net present value) 4,250 US \$, PI (profitability index) 1,06 and IRR (internal rate of returns) is $25,0 \%$.

\section{REFERENCES}

1. ANNONIME, Indnesia Rubber Bulletin, No,12/XXVII, December 15, (2005)

2. ASTA, Produksi sarung tangan Indonesia, WWW.nafed-go.id, October (2003)

3. ABDUL AZIZ BIN S.A. KADIR, Natural Rubber (Current Developments in Product Manufacture and Application), RRIM, Kuala Lumpur(1993)

4. BRIDSON, Rubbery Materials and Their Compounds, Elsevier Applied Science, London (1988)

5. HOFMAN W., Vulcanization and vulcanizing agents, Maclaren and sons Ltd., London (1967)

6. SBP, Hand Book of Rubber Technology with Product Formulation, SBP Industrial Technology Books Series No.72, BPP Consultant and Engineers Ltd. New Delhi (2000)

7. LEHARMAN E., and B.G.AUDLEY, Selecting the Righ Gloves, htt://www.imune. com/rubber/nr3.html, August 29, (1996)

8. MORALES C., ABASOMA, J.CARRBIRA, A.SASTRE, Anaphylaxis produced by rubber gloves content, Cure report and immunological identification of antigens involved, Chemical and Experimental Allergy, vol 19 (1989) 425-430

9. ABDUL AZIZ, S.A. KADIR, Latex Protein and Glove Industry, RRIM, Kuala Lumpur (1994) 104 pp

10. COLLYER A.A., Irradiation Effect on Polymers, Elsevier Applied Sci., London (1991)

11. MARGA UTAMA, H.M.HALIK, SISWANTO, Y.SYAMSU, H.HERWINARNI, SUHARYANTO, B.HANDOKO, Trial Production of Low Protein INRL in Factory Scale by Gamma Irradiation Technique, The 2003 A Workshop on The Utilization of Research Reactors. JakartaSerpong, January 12-16, (2004) (6 pages)

12. MARGA UTAMA, HERWINARNI, MADE SUMARTI, F.X. MARSONGKO, W.HERAWAN, S.MUDJIB, Production of pre- 
vulcanized natural rubber latex in factory scale, Proc. National Seminar on The Forth Chemical Process Technology, Faculty of Technology, Indonesia University, Jakarta March 31, (2004)

13. RIDWAN M, Ridwan.M. Pilot scale experiments on RVNRL, Radiation Phys. Chem., Vol.25 No.4-6, (1985), 887-892

14. SUNDARDI F., Review of radiation processing for NRL in Indonesia, Plastic Rubber processing and Application, vol. 5 (1985) 119-123

15. MARGA UTAMA,.. Production of rubber foam using radiation vulcanization technique, Proc. of The Second ASEAN-JAPAN Symposium. On Polymers, JICA-LIPI, Bandung (1992) 29

16. MARGA UTAMA, Trial Production of condom from INRL on Factory Scale, Frontiers of Polymers and Advantages Materials, Edited by Paras N Prassad, Plenum Press, New York (1994), 627

17. MARGA UTAMA, Trial Production of examination gloves from INRL on Factory Scale, Frontiers of Polymers and Advantages Materials, Edited by Paras N Prassad, Plenum Press, New York (1994) 649

18. MARGA UTAMA, Production of RVNRL and its rubber products, Presented at the fourth mission on RVNRL at PNRI, Quezon City Philippines, on 28 October - 9 November (1996)

19. MARGA UTAMA, YANTI SABARINAH, M.T.RAZZAK, SARI KUSUMAWATI, T.HARYANTO, Production of rubber thread from the mixture of RVNRL and MG latex, Proc. International Symposium on RVNRL, MINT, Kuala Lumpur (1996) 159

20. ASTM, Standard specification for latex concentrated, ammonia preserved, creamed, and centrifuging latex, ASTM D 412-(2002)

21. ASTM, Standard test method for rubber properties in tension, ASTM D 412-(2002)

22. ASTM, Standard test method for analysis of protein in natural rubber latex and its product, ASTM D 5712-95.

23. ASTM, Sphygmomanometer, ANSI/AAMI SP9-(1994)

24. ISO. Rubber Condom , ISO 40074 ; (1996)

25. ISO. Single-uses steril surgical rubber gloves-Specification, ISO 10282 (1994)

26. MARGA UTAMA, HERWINARNI, Economical analysis for production of INRL and adhesive by gamma irradiation in pilot scale, KMNRT, Jakarta (2003). Technical report 6 pages.

27. COLLYER A.A., Irradiation Effect on Polymers, Elsevier Applied Sci., London (1991) 
28. SPINKS J.W.T. and R.J.WOOD, An Introduction to Radiation Chemistry, John Wiley \& Sons, New York (1926)

29. EIRICH F.R., Science and Technology of Rubber, Academic Press, London (1978)

30. KHAIRINAGDI, Rubber as an Engineering Materials (Guideline for User), Hans Publisher, New York (1993)

31. WHITE J.L, Rubber Processing Technology Material Principle, Hanser Publication, New York (1995)

32. WILLOUGHBY B.G., and K.W. SCOTT, Nitrosamines in Rubber, RAPRA Technology, UK (1997) $88 \mathrm{p}$

33. SOEBIANTO Y.S., U,M,RATNAYAKE, K.MAKUUCHI, F.YOSHII, T.KUME, Soebianto Y.S., U.M.Ratnayake, K.Makuuchi, F.Yoshii, T.Kume, Extractable protein of RVNRL, Proc. of Radiation Processing of Natural Polymer, JAEI-Conf. 2000-2003, Takaskai. (2003) 49-55

34. VERGESE S, Y.KATSUMURA, K.MAKUUCHI, F.YOSHII, Production of soluble protein free latex by irradiation process, Rubber Chemistry and Technology, Vol.73, No.1 (2000) 80-88

35. MARGA UTAMA, Characterization of INRL produced in pilot scale, Regional Symposium on Polymer Science and Technology, LIPI-JICA, 25-26 November (1986)

36. MAKUUCHI K., An Introduction to RVNRL, Global Co. Ltd, Bangkok (2003) 